\title{
SENSITIVITAS MENDETEKSI BIAS BUTIR METODE UJI BEDA TARAF SUKAR, KHI-KUADRAT LORD, DAN DISTRIBUSI SAMPLING EMPIRIS
}

I Wayan Eka Mahendra

Institut Keguruan Ilmu Pendidikan

(IKIP) PGRI Bali

\author{
Alamat Korespondensi \\ Institut Keguruan Ilmu Pendidikan \\ (IKIP) PGRI \\ JI. Seroja, Denpasar, Bali \\ Indonesia \\ e-mail: \\ eka_undiksha@yahoo.com
}

\begin{abstract}
The objective of this study was to determine the effect of formative assessment and instructional approach toward the student's mathematics achievement upon controlling numerical talent. This study was a quasi-experimental study with 186 students as the samples which were selected by using multistage random sampling. This research adopted the $2 \times 2$ factorial experimental designs. The data from this study is analyzed by using analysis of covariance (ANCOVA). The results, after controlling the students' numerical talent, are as follows: the mathematics achievement of the student that participate in contextual teaching and learning approach is better than the students that participate in the conventional approach, the mathematics achievements of students that were given performance assessment are better than the students given conventional assessment. Further, there is an interaction effect of instructional approach and formative assessment towards the student's mathematics achievement. The group of students taught by using the contextual teaching and learning approach are more suitable to be assigned with performance assessment, where as the group of students taught by the conventional approach are more suitable to be assigned with conventional assessment. Based on the findings of the research, it is recommended to the teachers of the junior high schools that in improving the student's mathematics achievement, the teachers need to use instructional approach and formative assessment appropriately and correctly.
\end{abstract}

\section{Keywords}

Formative assessment, instructional approach, student achievement mathematics, numerical talent

\section{ABSTRAK}

Tujuan penelitian ini adalah untuk mengetahui pengaruh asesmen formatif dan pendekatan pembelajaran terhadap hasil belajar matematika, setelah mengendalikan bakat numerik. Penelitian ini adalah kuasi eksperimen dengan sampel sebanyak 186 siswa yang diambil dengan teknik multistage random sampling. Penelitian ini menggunakan desain faktorial $2 \times 2$. Data hasil penelitian dianalisis dengan ANCOVA. Hasilnya, setelah mengendalikan bakat numerik, adalah sebagai berikut. Hasil belajar matematika yang mengikuti pendekatan kontekstual lebih baik dari pada siswa yang mengikuti pendekatan pembelajaran konvensional, hasil belajar matematika siswa yang diberikan asesmen kinerja lebih baik dari pada siswa yang diberikan asesmen konvensional. Lebih lanjut terjadi pengaruh interaksi antara pendekatan pembelajaran dan bentuk asesmen formatif terhadap hasil belajar matematika siswa. Untuk siswa yang mengikuti pendekatan pembelajaran kontekstual lebih cocok diberikan asesmen kinerja, sedangkan untuk siswa yang mengikuti pendekatan pembelajaran konvensional lebih cocok diberikan asesmen konvensional. Berdasarkan temuan penelitian, disarankan kepada para guru SMP bahwa untuk meningkatkan hasil belajar matematika siswa, guru perlu menggunakan pendekatan pembelajaran dan penilaian formatif secara tepat dan benar.

\section{Kata Kunci}

Asesmen formatif, pendekatan pembelajaran, hasil belajar matematika, bakat numerik 


\section{Pendahuluan}

Hasil studi TIMSS dan PISA menunjukkan bahwa siswa kita rata-rata hanya mampu mengingat fakta, terminologi dan hukum-hukum matematika, tetapi menggunakan pengetahuan yang telah dimiliki untuk mengevaluasi, menganalisis, dan memecahkan permasalahan kehidupan masih amat kurang. Penyebabnya antara lain pada pembelajaran di kelas siswa Indonesia pada umumnya kurang terlatih untuk mengeriakan masalah-masalah yang berkaitan dengan kehidupan nyata siswa, serta instrumen penilaian hasil belajar yang substansinya kurang dikaitkan dengan konteks kehidupan yang dihadapi siswa dan kurang memfasilitasi siswa dalam mengungkapkan proses berpikir dan berargumentasi.

Sayangnya, proses pembelajaran matematika selama ini masih didominasi oleh guru. Guru lebih menekankan siswa untuk menghafal konsepkonsep, terutama rumus-rumus praktis, yang nantinya bisa digunakan oleh siswa dalam menjawab soal ulangan harian, ulangan umum, ataupun UAN tanpa melihat secara nyata manfaat materi yang diajarkan dalam kehidupan seharihari. Pembelajaran menjadi sangat analog dengan kegiatan menabung, di mana guru menjadi penabung dan siswa adalah celengannya. Pembelajaran semacam inilah yang disebut dengan istilah "gaya bank" (banking system) yang mengakibatkan siswa menjadi tidak memiliki keberanian untuk mengemukakan pendapat, tidak kreatif dan mandiri, apalagi untuk berpikir inovatif dan problem solving.

Guru harus melakukan inovasi pembelajaran di kelas, sehingga dapat memberi kesempatan secara luas pada siswa untuk belajar serta membangun pengetahuannya sendiri. Siswa harus menemukan dan mengkonstruksi sendiri pengetahuan di benak mereka sendiri dan memberi makna melalui pengalaman nyata. Pembelajaran akan bermakna bagi siswa bila dikaitkan dengan konteks kehidupan nyata. Pendekatan pembelajaran yang bertujuan menolong siswa melihat makna di dalam materi yang mereka pelajari dengan cara menghubungkan subjek-subjek materi ajar dengan konteks kehidupan keseharian mereka adalah pendekatan pembelajaran kontekstual.
Pendekatan pembelajaran kontekstual merupakan suatu proses pendidikan yang bertujuan membantu siswa melihat makna dalam bahan pelajaran yang mereka pelajari dengan cara menghubungkannya dengan kehidupan mereka sehari-hari, yaitu: dengan lingkungan pribadinya, sosialnya, dan budayanya (Johnson, 20I2; Sears, 2000). Kalchik dan Oertle (20I0) mengatakan bahwa pendekatan pembelajaran kontekstual adalah pendekatan pembelajaran yang dirancang untuk menghubungkan konten materi dengan situasi nyata dalam konteks tertentu yang menarik bagi siswa. Lebih jauh Sears (2000) mengungkapkan bahwa pendekatan pembelajaran kontekstual merupakan suatu proses pengajaran yang bertujuan untuk membantu siswa memahami materi pelajaran yang sedang mereka pelajari dengan menghubungkan pokok materi pelajaran dengan penerapannya dalam kehidupan seharihari.

Menurut Bernsdan Ericson (20I2), pendekatan pembelajaran kontekstual adalah konsepsi belajar mengajar yang membantu guru menghubungkan antara materi pelajaran dengan situasi dunia nyata, dan memotivasi siswa untuk membuat hubungan antara pengetahuan dan penerapannya untuk kehidupan mereka sebagai anggota keluarga, warga, dan pekerja, sehingga mendorong motivasi untuk bekerja keras menerapkan hasil belajarnya. Pendapat di atas menunjukkan beberapa istilah untuk menggambarkan pendekatan pembelajaran kontekstual, seperti: pengalaman nyata siswa, pendidikan dunia nyata, pembelajaran yang aktif, pembelajaran yang saling berkaitan (integrated learning), pembelajaran berbasis proyek (project based learning), sekolah untuk karier, dan pembelajaran terapan.

Selain penerapan pendekatan kontekstual diperlukan juga asesmen alternatif yang dapat memotivasi siswa untuk belajar, sehingga mengubah paradigma guru mengajar menjadi siswa belajar, dari pengalaman bermatematis guru menjadi pengalaman bermatematis siswa, fenomena mengajar untuk mengetes dan belajar untuk tes menjadi mengakses untuk belajar. Lee (2000) mengatakan asesmen merupakan komponen integral dalam belajar dan mengajar. Asesmen adalah suatu tindakan dalam 
mengumpulkan informasi tentang siswa atau kelompok siswa untuk mengetahui dan memahami kemampuan siswa (Butler, 2006). Asesmen alternatif yang dapat digunakan adalah asesmen kinerja. Beberapa ahli kadang-kadang menggunakan istilah asesmen autentik untuk menjelaskan asesmen kinerja karena tugas-tugas asesmennya lebih dekat dengan kehidupan nyata siswa (Nitko, 1996).

The Office of Technology Assessment (OTA) seperti dikutip Elliott (1985) mendefinisikan asesmen kinerja sebagai metode pengujian yang mengharuskan siswa untuk membuat jawaban atau produk yang menunjukkan pengetahuan dan keterampilan mereka, penilaian kinerja dapat mengambil berbagai bentuk, termasuk melakukan eksperimen, menulis esai diperpanjang dan melakukan perhitungan matematis. Nitko (1996) mendefinisikan asesmen kinerja adalah suatu prosedur penugasan kepada siswa guna mengumpulkan informasi sejauh mana siswa telah belajar. Senada dengan Nitko, Danielson (2006) mengungkapkan asesmen kinerja adalah asesmen belajar siswa yang meliputi semua penilaian dalam bentuk tulisan, produk atau sikap kecuali bentuk pilihan ganda, menjodohkan, benar-salah, atau jawaban singkat. Tes essay jawaban terbuka merupakan salah satu contoh yang sangat umum dari suatu asesmen berbasis kinerja, tetapi ada banyak contoh lain, meliputi produksi artistik, eksperimen dalam sains, presentasi lisan, dan menggunakan matematika untuk menyelesaikan masalah dunia nyata.

Istilah bakat dalam bahasa Inggris aptitude, disebut juga talent. Bakat adalah kemampuan yang merupakan sesuatu "inheren" (melekat) dalam diri seseorang, dibawa sejak lahir dan terkait dengan struktur otak (Semiawan, 1997). Kerlinger (1990) menyatakan bahwa bakat atau aptitude adalah kemampuan potensial untuk berhasil di bidang tertentu. Sistem numerik merupakan bagian dari sistem matematika. Sekalipun sebagai cabang, sistem numerik telah menelusuri seluruh tubuh matematika. Sistem numerik ada dalam aljabar, geometri, peluang, statistika, dan teori fungsi. Bakat numerik adalah bakat tentang keterampilan matematika umum yang bekerja dengan angka dengan cepat dan akurat (Carter, 2007). Bakat numerik dalam hal ini menyangkut dimensi intelektual yang merupakan kemampuan potensial yang dimiliki oleh siswa dalam melakukan operasi hitung secara manual seperti meliputi operasi penjumlahan, pengurangan, perkalian, pembagian, maupun operasi hitung campuran yang akan memungkinkan untuk berkembang dan berhasil di bidang matematika.

Tujuan utama penelitian ini adalah untuk mengetahui pengaruh bentuk asesmen formatif dan pendekatan pembelajaran terhadap hasil belajar matematika, pada siswa kelas VII Sekolah Menengah Pertama (SMP) Negeri di Kecamatan Marga, setelah mengontrol bakat numerik.

\section{Metode Penelitian}

Penelitian ini dilakukan di SMP Negeri 3 dan 4 Marga, Kabupaten Tabanan, Provinsi Bali. Penelitian dilakukan selama empat bulan, yaitu: pada semester pertama tahun ajaran 2013/2014, mulai bulan Juli sampai dengan Oktober 2013, dengan metode kuasi eksperimen dan desain faktorial $2 \times 2$ melibatkan sampel sebanyak 186 orang yang diambil dengan teknik multistage random sampling. Data bakat numerik siswa dikumpulkan dengan tes bakat numerik dalam bentuk pilihan ganda dengan koefisien reliabilitas 0,924; dan data hasil belajar matematika dikumpulkan dengan tes hasil belajar bentuk uraian dengan koefisien reliabilitas 0,796. Teknik analisis data yang digunakan adalah analisis kovarians (ANAKOVA). Hipotesis yang diuji adalah hipotesis efek utama (main effect), hipotesis interaksi (interaction effect), dan hipotesis sederhana (simple effect).

Teknik analisis data yang digunakan dalam penelitian ini berupa analisis deskriptif, analisis terhadap uji persyaratan yang meliputi uji normalitas sebaran data, uji linieritas dan keberartian arah regresi, uji homogenitas varians serta uji kesejajaran garis regresi yang telah terpenuhi, dan analisis inferensial. Ketiga analisis ini dilakukan berdasarkan data bakat numerik siswa yang diperoleh dan skor hasil belajar matematika siswa setelah perlakuan pendekatan pembelajaran dan bentuk asesmen formatif.

\section{Hasil Penelitian dan Pembahasan}

Berdasarkan nilai statistik uji-F, diperoleh nilai $F_{\text {hitung }}=10,769$ lebih dari nilai $F_{\text {tabel }}$ dengan 
$\mathrm{db}_{\text {pembilang }}=1$ dan $\mathrm{db}_{\text {penyebut }}=181$ sebesar 3,89 dengan taraf signifikansi $\alpha=0,05$; ini berarti $F_{\text {hitung }}$ $>F_{\text {tabel }}(10,769>3,89)$. Sehingga $\mathrm{H}_{0}$ ditolak dan $\mathrm{H}_{\mathrm{a}}$ diterima, yang berarti bahwa terdapat perbedaan hasil belajar matematika antara kelompok siswa yang mengikuti pendekatan pembelajaran kontekstual, dengan kelompok siswa yang mengikuti pendekatan pembelajaran konvensional, setelah mengontrol bakat numerik. Untuk mengetahui kelompok mana yang lebih tinggi rerata skor hasil belajarnya dapat dilihat dari nilai rata-rata terkoreksi kedua kelompok tersebut. Dari hasil analisis terlihat bahwa skor rerata terkoreksi hasil belajar matematika pada kelompok siswa yang mengikuti pendekatan pembelajaran kontekstual adalah 38,35; sedangkan skor rerata terkoreksi hasil belajar matematika pada kelompok siswa yang mengikuti pendekatan pembelajaran konvensional adalah 34,8I. Dapat kesimpulan bahwa hasil belajar matematika siswa yang mengikuti pendekatan pembelajaran kontekstual lebih baik dari pada siswa yang mengikuti pendekatan pembelajaran konvensional, setelah mengontrol bakat numerik.

Berdasarkan nilai statistik uji- $F$ diperoleh, $F_{\text {hitung }}$ $=6,217$ lebih dari nilai $F_{\text {tabel }}$ dengan $\mathrm{db}_{\text {pembilang }}=1$ dan $\mathrm{db}_{\text {penyebut }}=|8|$ sebesar 3,89 dengan taraf signifikansi $\alpha=0,05$; ini berarti $F_{\text {hitung }}>F_{\text {tabel }}(6,217$ $>3,89$ ). Sehingga $H_{0}$ ditolak dan $H_{a}$ diterima, yang berarti bahwa terdapat perbedaan hasil belajar matematika antara kelompok siswa yang diberikan asesmen kinerja, dengan kelompok siswa yang diberikan konvensional, setelah mengontrol bakat numerik. Untuk mengetahui kelompok mana yang lebih tinggi rerata skor hasil belajarnya dapat dilihat dari nilai rata-rata terkoreksi kedua kelompok tersebut. Dari hasil analisis terlihat bahwa skor rerata terkoreksi hasil belajar matematika pada kelompok siswa yang diberikan asesmen kinerja adalah 37,93; sedangkan skor rerata hasil belajar matematika pada kelompok siswa yang diberikan asesmen konvensional adalah 35,28. Dapat kesimpulan bahwa hasil belajar matematika siswa yang diberikan asesmen kinerja lebih baik daripada siswa yang diberikan asesmen konvensional setelah mengontrol bakat numerik.

Dari hasil analisis pengujian hipotesis ketiga menunjukkan bahwa nilai statistik Uji-F diperoleh nilai $F_{\text {hitung }}=46,528$ yang lebih dari $F_{\text {tabel }}$ dengan $\mathrm{dk}_{\text {pembilang }}=\mathrm{I}$ dan $\mathrm{dk}_{\text {penyebut }}=181$ sebesar 3,89 pada taraf signifikansi $\alpha=0,05$. Sehingga $H_{0}$ ditolak yang berarti terdapat pengaruh interaksi antara pendekatan pembelajaran dan bentuk asesmen formatif terhadap hasil belajar matematika, setelah mengontrol bakat numerik.

Berdasarkan hasil analisis pengujian hipotesis, menunjukkan bahwa nilai statistik uji-t baris diperoleh nilai $t_{\text {hitung }}=7,181$ lebih dari nilai $t_{\text {tabel }}$ dengan $\mathrm{db}=\mathrm{db}_{\text {dalam }}=181$ sebesar 1,645 dengan taraf signifikansi $\alpha=0,05$ ini berarti $t_{\text {hitung }}>t_{\text {tabel }}$ $(7,18 I>1,645)$. Sehingga $H_{0}$ ditolak, yang berarti bahwa untuk siswa yang diberikan asesmen kinerja, terdapat perbedaan hasil belajar matematika antara siswa yang mengikuti pendekatan pembelajaran kontekstual dengan siswa yang mengikuti pendekatan pembelajaran konvensional, setelah mengontrol bakat numerik. Lebih jauh dapat dilihat nilai rata-rata terkoreksi antara kedua kelompok tersebut, terlihat bahwa untuk siswa yang diberikan asesmen kinerja, hasil belajar matematika siswa yang mengikuti pendekatan pembelajaran kontekstual adalah sebesar 43,02 dan siswa yang mengikuti pendekatan pembelajaran konvensional adalah sebesar 32,32. Dapat disimpulkan bahwa untuk siswa yang diberikan asesmen kinerja, hasil belajar matematika siswa yang mengikuti pendekatan pembelajaran kontekstual lebih tinggi daripada siswa yang mengikuti pendekatan pembelajaran konvensional, setelah mengontrol bakat numerik.

Berdasarkan hasil analisis pengujian hipotesis, menunjukkan bahwa nilai statistik uji-t diperoleh nilai $t_{\text {hitung }}=2,489$ lebih dari nilai $t_{\text {tabel }}$ dengan $\mathrm{db}=$ $\mathrm{db}_{\text {dalam }}=18 \mathrm{I}$ sebesar $\mathrm{I}, 645$ dengan taraf signifikansi $\alpha=0,05$, ini berarti $t_{\text {hitung }}>t_{\text {tabel }}(2,489$ $>1,645)$. Sehingga $H_{0}$ ditolak, yang berarti bahwa untuk siswa yang diberikan asesmen konvensional, terdapat perbedaan hasil belajar matematika antara siswa yang mengikuti pendekatan pembelajaran kontekstual dengan siswa yang mengikuti pendekatan pembelajaran konvensional, setelah mengontrol bakat numerik. Lebih jauh dapat dilihat nilai rata-rata terkoreksi antara kedua kelompok tersebut, terlihat bahwa untuk siswa yang diberikan asesmen konvensional, hasil belajar matematika siswa yang mengikuti pendekatan pembelajaran kontekstual adalah sebesar 33,59 dan siswa yang mengikuti pendekatan pembelajaran konvensional adalah 
sebesar 37,05. Dapat disimpulkan bahwa untuk siswa yang diberikan asesmen konvensional, hasil belajar matematika siswa yang mengikuti pendekatan pembelajaran kontekstual lebih rendah daripada siswa yang mengikuti pendekatan pembelajaran konvensional, setelah mengontrol bakat numerik.

Berdasarkan hasil analisis pengujian hipotesis, menunjukkan bahwa nilai statistik uji-t diperoleh nilai $t_{\text {hitung }}=9,583$ lebih dari nilai $t_{\text {tabel }}$ dengan $\mathrm{db}_{\text {dalam }}=18 \mathrm{I}$ sebesar $\mathrm{I}, 645$ dengan taraf signifikansi $\alpha=0,05$ ini berarti $t_{\text {hitung }}>t_{\text {tabel }}(9,583$ $>1,645)$. Sehingga $H_{0}$ ditolak, yang berarti bahwa untuk siswa yang mengikuti pendekatan pembelajaran kontekstual, terdapat perbedaan hasil belajar matematika antara siswa yang diberikan asesmen kinerja dengan siswa yang diberikan asesmen konvensional, setelah mengontrol bakat numerik. Lebih jauh dapat dilihat nilai rata-rata terkoreksi antara kedua kelompok tersebut, terlihat bahwa untuk siswa yang mengikuti pendekatan pembelajaran kontekstual, hasil belajar matematika siswa yang diberikan asesmen kinerja adalah sebesar 43,02 dan siswa yang diberikan asesmen konvensional adalah sebesar 33,59. Dapat disimpulkan bahwa untuk siswa yang mengikuti pendekatan pembelajaran kontekstual, hasil belajar matematika siswa yang diberikan asesmen kinerja lebih baik daripada siswa yang diberikan asesmen konvensional, setelah mengontrol bakat numerik.

Berdasarkan hasil analisis pengujian hipotesis, menunjukkan bahwa nilai statistik uji-t diperoleh nilai $\mathrm{t}_{\text {hitung }}=4,443$ lebih dari nilai $\mathrm{t}_{\text {tabel }}$ dengan $\mathrm{db}_{\text {dalam }}=181$ sebesar $\mathrm{I}, 645$ dengan taraf signifikansi $\alpha=0,05$ ini berarti $t_{\text {hitung }}>t_{\text {tabel }}(4,443$ $>1,645)$. Sehingga $H_{0}$ ditolak, yang berarti untuk siswa yang mengikuti pendekatan pembelajaran konvensional, terdapat perbedaan hasil belajar matematika antara siswa yang diberikan asesmen kinerja dengan siswa yang diberikan asesmen konvensional, setelah mengontrol bakat numerik. Lebih jauh dapat dilihat nilai rata-rata terkoreksi antara kedua kelompok tersebut, terlihat bahwa untuk siswa yang mengikuti pendekatan pembelajaran konvensional, hasil belajar matematika siswa yang diberikan asesmen kinerja adalah sebesar 32,32 dan siswa yang diberikan asesmen konvensional adalah sebesar 37,05. Dapat disimpulkan bahwa untuk siswa yang mengikuti pendekatan pembelajaran konvensional, hasil belajar matematika siswa yang diberikan asesmen kinerja lebih rendah daripada siswa yang diberikan asesmen konvensional, setelah mengontrol bakat numerik.

Hasil belajar matematika siswa yang mengikuti pendekatan pembelajaran kontekstual lebih tinggi daripada siswa yang mengikuti pendekatan pembelajaran konvensional, setelah mengontrol bakat numerik. Dengan demikian dapat disimpulkan bahwa dalam pembelajaran matematika pada dua Sekolah Menengah Pertama (SMP) Negeri di Kecamatan Marga tempat berlangsungnya penelitian ini, diperoleh bahwa penerapan pendekatan pembelajaran kontekstual lebih tinggi dalam pencapaian hasil belajar, dibandingkan dengan penerapan pendekatan pembelajaran konvensional, setelah mengontrol bakat numerik.

Pernyataan hasil penelitian di atas didukung oleh kajian teori bahwa belajar matematika tidak hanya sekadar belajar tentang konsep-konsep tetapi belajar secara bermakna. Bermakna dalam hal ini siswa tahu tujuan mereka belajar matematika. Siswa belajar bermakna jika materi dalam pembelajarannya dikaitkan dengan kehidupan nyata yang dekat dengan keseharian siswa. Oleh sebab itu proses pembelajaran matematika harus dapat menghubungkan antara ide abstrak matematika dengan situasi dunia nyata yang pernah dialami ataupun yang pernah dipikirkan siswa, karena matematika muncul dari kehidupan nyata sehari-hari. Sebagai contoh, bangun ruang dan datar pada dasarnya didapat dari benda-benda kongkrit dengan melakukan proses abstraksi dari benda-benda nyata.

Proses belajar matematika dapat diawali dengan benda-benda nyata (real) kemudian sedikit demi sedikit mengarah ke konsep yang abstrak. Untuk itu diperlukan suatu pendekatan pembelajaran yang mampu mengaitkan materi yang dipelajari siswa dengan kehidupan mereka sehari-hari. Pendekatan pembelajaran yang dapat mengaitkan materi pelajaran dengan kehidupan siswa adalah pendekatan pembelajaran kontekstual.

Salah satu tujuan belajar matematika adalah untuk mempersiapkan siswa agar dapat menggunakan matematika dan pola pikir matematika dalam kehidupan sehari-hari dan 
dalam mempelajari berbagai ilmu pengetahuan, sehubungan dengan itu siswa memerlukan matematika untuk memenuhi kehidupan praktis dan memecahkan persoalan dalam kehidupan sehari-hari, selain itu agar siswa mampu memahami bidang studi lain, berpikir logis, kritis, rasional, praktis, serta bersifat positif dan kreatif. $\mathrm{Hal}$ ini jelas merupakan tuntutan yang sangat tinggi yang tidak dapat dicapai hanya dengan menilai hafalan, latihan pengerjaan soal yang bersifat rutin, serta proses pembelajaran biasa (konvensional).

Untuk menjawab tuntutan yang demikian tinggi, perlu dikembangkan materi serta proses pembelajaran yang sesuai. Pembelajaran yang memungkinkan untuk mencapai hal tersebut adalah melalui pendekatan pembelajaran kontekstual, karena fokus pendekatan pembelajaran kontekstual adalah pada pengaitan materi yang dipelajari siswa dengan masalahmasalah yang dihadapi siswa dalam kehidupan sehari-hari. Penerapan strategi yang dipilih dalam pembelajaran matematika haruslah mampu mengoptimalisasikan interaksi seluruh unsur pembelajaran. Demi peningkatan optimalisasi interaksi dalam pembelajaran matematika, untuk pokok bahasan atau sub pokok bahasan tertentu mungkin dapat dicapai dengan pendekatan pembelajaran kontekstual. Pendukung CTL menegaskan bahwa dalam banyak hal CTL dapat memotivasi siswa lebih efektif belajar dari pada pendekatan kelas tradisional (Kalchik dan Marie Oertle, 2010).

Dalam pendekatan pembelajaran kontekstual siswa mengkonstruksi pengetahuannya sendiri, menemukan sendiri aturan, siswa bebas berdiskusi dengan temannya, siswa bebas bertanya kepada guru serta memungkinkan siswa lebih mudah mengingat urutan materi yang dipelajarinya. Akibatnya pemahaman siswa tentang suatu konsep matematika akan lebih baik dibandingkan pemahaman konsep hasil informasi dari guru. tentunya hal ini akan dapat meningkatkan hasil belajar siswa.

Berdasarkan uraian di atas terlihat adanya kesesuaian antara belajar matematika dengan pendekatan pembelajaran kontekstual. Di satu sisi proses pembelajaran matematika harus dapat menghubungkan antara ide abstrak matematika dengan situasi dunia nyata yang pernah dialami ataupun yang pernah dipikirkan siswa. Di sisi lain, pendekatan pembelajaran kontekstual adalah konsep belajar yang mengaitkan materi pembelajaran dengan situasi dunia nyata siswa dan mendorong siswa membuat hubungan antara pengetahuan yang dimilikinya dengan penerapannya dalam kehidupan mereka sebagai anggota keluarga dan masyarakat.

Dengan adanya kesesuaian antara hakikat pembelajaran matematika dengan pendekatan pembelajaran kontekstual, maka wajar kalau hasil belajar matematika siswa yang mengikuti pendekatan pembelajaran kontekstual lebih baik daripada hasil belajar matematika siswa yang mengikuti pendekatan pembelajaran konvensional. $\mathrm{Hal}$ ini sesuai dengan hasil penelitian yang menunjukkan bahwa pendekatan pembelajaran kontekstual dapat meningkatkan kemampuan pemecahan masalah matematika dan hasil belajar matematika (Ariesta, 2012; Gita, 2004; dan Putra, 20I2). Berbagai temuan tersebut mengindikasikan kalau pendekatan pembelajaran kontekstual cocok diterapkan dalam pembelajaran matematika.

Hasil belajar matematika siswa yang diberikan asesmen kinerja lebih tinggi daripada siswa yang diberikan asesmen konvensional setelah mengontrol bakat numerik. Untuk mengetahui kelompok mana yang lebih tinggi rerata skor hasil belajarnya dapat dilihat dari nilai rata-rata dikoreksi kedua kelompok tersebut. Dari hasil analisis terlihat bahwa skor rerata hasil belajar matematika pada kelompok siswa yang diberikan asesmen kinerja adalah 38,04; sedangkan skor rerata hasil belajar matematika pada kelompok siswa yang diberikan asesmen konvensional adalah 35, 16.

Asesmen kinerja adalah suatu prosedur penugasan kepada siswa guna mengumpulkan informasi sejauh mana siswa telah belajar. Asesmen ini menghendaki siswa untuk menerapkan pengetahuan dan keterampilannya untuk menunjukkan penguasaan mereka terhadap target pembelajaran. Asesmen kinerja merupakan salah satu penilaian di mana guru mengamati dan membuat pertimbangan tentang apa yang diketahui dan dapat dilakukan siswa dalam belajarnya.

Salah satu keuntungan dari asesmen kinerja adalah dapat memotivasi siswa untuk belajar, 
siswa akan dilatih untuk dapat berpikir kritis, cepat, dan mengetahui kelebihan serta kelemahannya dalam pembelajaran. Motivasi merupakan salah satu faktor penting yang dapat mempengaruhi tingkat hasil belajar siswa. Adanya motivasi belajar yang kuat membuat siswa belajar dengan tekun dan pada akhirnya terwujud dalam hasil belajar siswa tersebut. Makin kuat dorongan untuk belajar, makin tinggi pula hasil yang akan dicapai. Asesmen kinerja yang dilakukan oleh guru juga memberikan banyak kontribusi dalam meningkatkan hasil belajar siswa.

Melalui asesmen kinerja yang dilakukan dalam pembelajaran, siswa merasa bahwa tugas-tugas yang mereka kerjakan benar-benar bermakna dan mereka langsung mengetahui tingkat pengetahuannya terhadap suatu permasalahan. Keuntungan asesmen kinerja ini juga didukung oleh hasil penelitian Al-sadaawi (2008) yang menunjukkan bahwa variasi $23 \%$ hasil belajar siswa (hasil post tes) disebabkan oleh asesmen kinerja. Hal ini menunjukkan bahwa asesmen kinerja memiliki kontribusi yang cukup signifikan terhadap hasil belajar siswa.

Pemahaman matematika siswa akan lebih baik dengan penerapan asesmen kinerja dibandingkan dengan asesmen konvensional, karena dengan asesmen kinerja siswa diberikan pengalaman untuk menemukan dan melakukan sesuai dengan kompetensi yang diinginkan. Dengan unjuk kerja sebagai salah satu bentuk penilaian autentik, peserta didik dituntut untuk melakukan sesuatu sesuai dengan kompetensi yang ingin dicapai, sehingga mereka mengalaminya sendiri, tidak hanya dengan mendengarkan cerita dari guru. Mereka dapat pemahaman yang nyata apa yang mereka ketahui dan apa yang dapat mereka kerjakan, tidak memberikan ancaman sehingga dapat mengatasi ketakutan dalam belajar matematika dan akhirnya dapat meningkatkan motivasinya untuk mempelajari matematika. Penerapan asesmen kinerja dalam pembelajaran matematika dapat meningkatkan pemahaman matematika, meningkatkan keterampilan, meningkatkan kemandirian belajar peserta didik, dan meningkatkan aktivitas dalam pembelajaran yang nantinya bermuara pada meningkatnya hasil belajar matematika siswa.

Hasil pengujian hipotesis ketiga menunjukkan bahwa terdapat pengaruh interaksi antara pendekatan pembelajaran dan bentuk asesmen formatif terhadap hasil belajar matematika, setelah mengontrol bakat numerik.

Pendekatan pembelajaran kontekstual adalah suatu konsep belajar yang membantu guru mengaitkan materi yang diajarkannya dengan situasi dunia nyata dan mendorong siswa membuat hubungan antara pengetahuan yang dimiliki dengan penerapannya dalam kehidupan mereka sebagai anggota keluarga dan masyarakat. Dengan konsep seperti itu, proses pembelajaran akan berlangsung secara bermakna. Proses pembelajaran akan berlangsung secara alamiah dalam bentuk kegiatan bekerja dan mengalami, bukan "transfer" pengetahuan dari guru ke siswa. Proses pembelajaran lebih utama daripada hasil pembelajaran. Salah satu komponen penting pendekatan pembelajaran kontekstual adalah asesmen autentik. Asesmen autentik sering diidentikkan dengan asesmen kinerja, dengan kata lain asesmen autentik adalah sinonim dari asesmen kinerja. Dengan demikian asesmen kinerja merupakan salah satu komponen dari pendekatan pembelajaran kontekstual.

Asesmen kinerja matematika adalah suatu bentuk penilaian terhadap presentasi tugas matematika, kemampuan memecahkan masalah matematika, proyek matematika, observasi, dan hasil kerja (produk) yang menggambarkan kemampuan siswa melalui suatu proses, kegiatan, unjuk kerja maupun hasil dari cerminan proses yang dilakukan oleh siswa. Sifat kegiatan dari asesmen kinerja berdasarkan kehidupan nyata. Oleh karena itu, terlihat adanya kesesuaian antara penggunaan asesmen kinerja dalam pembelajaran dengan pendekatan pembelajaran kontekstual, yaitu: sama-sama berdasarkan kehidupan nyata siswa. Pelaksanaan asesmen kinerja menuntut guru dan siswa melakukan aktivitas yang tinggi dalam pembelajaran. Hal ini tentunya dapat difasilitasi oleh pendekatan pembelajaran kontekstual, karena dalam penerapannya memberikan ruang yang cukup pada siswa untuk bekerja dan mengalami.

Pembelajaran konvensional merupakan pembelajaran yang biasa dilakukan guru dalam proses belajar mengajar di dalam kelas. Pada pembelajaran konvensional, proses belajar mengajar lebih sering diarahkan pada "aliran informasi" atau "transfer" pengetahuan dari guru 
ke siswa. Konsep yang diterima siswa hampir semuanya berasal dari "apa kata guru". Siswa terlatih seperti "burung beo" yang hanya pintar meniru tapi sulit sekali menciptakan sendiri. Guru akan merasa bangga ketika anak didiknya mampu menyebutkan kembali secara lisan (verbal) sebagian besar informasi yang terdapat dalam buku teks atau yang diberikan oleh guru.

Dalam pendekatan ini asesmen konvensional dalam bentuk paper and pencil test (tes standar) sangat sesuai digunakan, walau memiliki beberapa kelemahan. Perkembangan penggunaan tes, khususnya tes pilihan ganda disebabkan karena sistem testing memiliki beberapa kelebihan, seperti: dapat menjangkau materi yang luas, dapat dilaksanakan dalam waktu yang relatif singkat serta dapat diperiksa dengan cepat. Tidak mengherankan apabila tes pilihan ganda menjadi tren dan penggunaannya menjadi populer selama bertahun-tahun. Dalam pendekatan pembelajaran konvensional asesmen kinerja kurang diberikan ruang yang cukup dalam penerapannya, karena yang aktif dalam pembelajaran adalah guru bukan siswa.

Penjelasan di atas menunjukkan bahwa bila asesmen kinerja dipertimbangkan dugaan tentang pengaruh pendekatan pembelajaran terhadap hasil belajar matematika akan berlawanan. Pada siswa yang diberikan asesmen kinerja diduga hasil belajar matematika siswa yang mengikuti pendekatan pembelajaran konvensional lebih baik dari pada siswa yang mengikuti pendekatan pembelajaran kontekstual. Sebaliknya, pada siswa yang diberikan asesmen konvensional diduga hasil belajar matematika siswa yang mengikuti pendekatan pembelajaran konvensional lebih baik dari pada siswa yang mengikuti pendekatan pembelajaran kontekstual.

Dengan demikian wajar terdapat interaksi antara pendekatan pembelajaran dengan bentuk asesmen formatif yang digunakan dalam pengaruhnya terhadap hasil belajar matematika, setelah mengontrol bakat numerik.

Hasil pengujian hipotesis keempat menunjukkan bahwa untuk siswa yang diberikan asesmen kinerja, hasil belajar matematika siswa yang mengikuti pendekatan pembelajaran kontekstual lebih tinggi daripada siswa yang mengikuti pendekatan pembelajaran konvensional, setelah mengontrol bakat numerik.
Keterlaksanaan asesmen kinerja dalam pembelajaran tergantung dan sangat ditentukan oleh tingkat keaktifan guru dan peserta didik selama mengikuti proses pembelajaran. Makin tinggi tingkat keaktifan dan kekreatifan peserta didik dan guru makin tinggi pula tingkat keefektifan pelaksanaan asesmen kinerja. Sebaliknya, makin rendah tingkat keaktifan kreativitas peserta didik dan guru makin rendah pula tingkat keefektifan asesmen kinerja bahkan mungkin tidak dapat berjalan dengan baik. Oleh karena itu, guru harus mampu merancang dan melaksanakan suatu program pengajaran yang mampu membuat siswa aktif dan kreatif. Pembelajaran yang mampu membuat siswa aktif dan kreatif adalah pendekatan pembelajaran kontekstual.

Asesmen kinerja dapat tercapai dengan baik diperlukan perubahan pandangan dari guru terhadap proses pembelajaran, yakni: (I) guru tidak lagi memandang dirinya sebagai sumber belajar, sedangkan peserta didik dipandang sebagai unsur yang harus diisi penuh dengan materi yang disampaikan oleh guru; (2) materi pelajaran yang terdapat dalam dokumen kurikulum tidak harus disampaikan dalam kegiatan tatap muka di kelas, tetapi dapat disampaikan melalui tugas, proyek, atau simulasi dan lain-lain; (3) guru harus memulai sedikit demi sedikit mengaitkan materi pelajaran matematika dengan kehidupan dunia nyata, sehingga pembelajaran akan lebih bermakna. Proses pembelajaran seperti ini akan dicapai dengan pendekatan pembelajaran kontekstual. Melalui pendekatan ini proses belajar mengajar, termasuk pelaksanaan asesmennya dilakukan bersama-sama antara guru dengan peserta didik. Hal ini sesuai dengan penelitian Kadir (2009) yang menunjukkan bahwa asesmen kinerja masalah lebih cocok dengan pembelajaran kooperatif dan asesmen pengajuan masalah lebih cocok dengan asesmen kinerja pengajuan masalah.

Melihat uraian di atas, nampaknya asesmen kinerja kurang cocok digunakan dalam pembelajaran dengan pendekatan pembelajaran konvensional, sebab kurang diberikan ruang yang cukup dalam penerapannya ini terjadi karena siswa pasif dan guru aktif dalam pembelajaran. Guru akan kesulitan mengakses penampilan siswa di dalam kelas. Hal ini mengakibatkan apa yang diakses oleh guru tidak maksimal, sehingga 
hasilnyapun tidak maksimal. Sehingga asesmen kinerja menjadi kumpulan tugas yang tidak bermakna bagi peserta didik dan guru. Pemahaman matematika siswa akan lebih baik dengan penerapan asesmen kinerja dibandingkan dengan asesmen konvensional, karena dengan asesmen kinerja siswa diberikan pengalaman untuk menemukan dan melakukan sesuai dengan kompetensi yang diinginkan.

Fenomena di atas menunjukkan bahwa bentuk asesmen yang digunakan dalam mengakses hasil belajar matematika siswa harus disesuaikan dengan pendekatan pembelajaran yang dirancang oleh guru. Tujuannya untuk menghasilkan informasi yang maksimal tentang pengetahuan siswa yang nantinya dapat sebagai umpan balik dalam memotivasi siswa untuk belajar.

Dengan demikian wajar hasil belajar matematika siswa yang mengikuti pendekatan pembelajaran kontekstual lebih tinggi dari pada siswa yang mengikuti pendekatan pembelajaran konvensional, setelah mengontrol bakat numerik.

Hasil pengujian hipotesis kelima menunjukkan bahwa untuk siswa yang diberikan asesmen konvensional, hasil belajar matematika siswa yang mengikuti pendekatan pembelajaran kontekstual lebih rendah daripada siswa yang mengikuti pendekatan pembelajaran konvensional, setelah mengontrol bakat numerik.

Pendekatan pembelajaran kontekstual bertujuan untuk membantu siswa memahami materi pelajaran yang sedang mereka pelajari dengan menghubungkan pokok materi pelajaran dengan penerapannya dalam kehidupan seharihari. Pendekatan pembelajaran kontekstual mengarah pada pembelajaran yang dilandasi oleh suatu asesmen, sehingga guru harus merencanakan aktivitas pengajaran yang sesuai dengan tahap perkembangan siswa, baik mengenai kelompok belajar, fasilitas belajar, maupun asesmen, sehingga pembelajaran mengarah pada peningkatan kecerdasan kognitif, afektif, dan psikomotor siswa.

Salah satu komponen dari pendekatan pembelajaran kontekstual adalah asesmen autentik. Asesmen autentik menitik beratkan pada penilaian proses dengan tanpa mengenyampingkan penilaian hasil. $\mathrm{Hal}$ ini didasarkan bahwa sebenarnya pembelajaran seharusnya ditekankan pada upaya membantu siswa agar mampu mempelajari materi, tetapi bukan ditekankan pada diperolehnya sebanyak mungkin informasi di akhir satuan pembelajaran. Ini berarti informasi dikumpulkan oleh siswa selama pembelajaran maupun setelah pembelajaran.

Pengumpulan informasi tidak saja dari guru, tetapi bisa dari teman sejawat atau orang lain yang terlibat dalam pembelajaran. Tentunya hal ini kurang tepat apabila apa yang dipahami siswa hanya diakses dengan asesmen konvensional, karena dapat menurunkan motivasi belajar siswa sehingga nantinya dapat menurunkan hasil belajar siswa.

Dalam pendekatan pembelajaran konvensional indikator yang sering digunakan untuk menilai kualitas pembelajaran adalah hasil belajar siswa yang direpresentasikan oleh hasil tes. Dampak dari pandangan tersebut diperkuat dengan bentuk asesmen yang digunakan, yaitu: asesmen konvensional berupa tes-tes standar (paper and pencil test). Bahkan guru berlomba-lomba untuk mentransfer materi pelajaran untuk mempersiapkan siswa menghadapi ujian. Dalam pendekatan pembelajaran konvensional siswa seolah-olah dipaksa untuk menerima informasi dari guru tanpa memberikan kesempatan sedikitpun untuk melaksanakan refleksi secara kritis. Keadaan di atas juga membuat guru enggan melakukan kegiatan pembelajaran yang berfokus pada aktivitas anak untuk melakukan keterampilan proses. Dengan kondisi seperti ini asesmen konvensional akan lebih tepat digunakan dalam mengakses kemampuan siswa, walaupun tidak menyeluruh. Hal ini sesuai dengan penelitian Kadir (2009) yang menunjukkan metakognisi siswa yang diberikan asesmen kinerja pengajuan masalah lebih baik daripada siswa yang diberikan asesmen pemecahan masalah, dalam setting pembelajaran konvensional.

Dengan demikian wajar hasil belajar matematika siswa yang mengikuti pendekatan pembelajaran kontekstual lebih rendah daripada siswa yang mengikuti pendekatan pembelajaran konvensional, setelah mengontrol bakat numerik.

Hasil pengujian hipotesis ketujuh menunjukkan bahwa untuk siswa yang mengikuti pendekatan pembelajaran kontekstual, hasil belajar matematika siswa yang diberikan asesmen kinerja 
lebih tinggi daripada siswa yang diberikan asesmen konvensional, setelah mengontrol bakat numerik.

Pembelajaran matematika dengan pendekatan pembelajaran kontekstual terjadi ketika siswa menerapkan dan mengalami apa yang diajarkan dengan mengacu pada masalah-masalah riil (nyata) yang berasosiasi dengan peran dan tanggung jawab mereka sebagai anggota keluarga, anggota masyarakat, siswa, dan selaku pekerja. Pendekatan pembelajaran kontekstual mengakui bahwa belajar hanya terjadi jika siswa memproses informasi atau pengetahuan baru sedemikian rupa sehingga dirasakan masuk akal sesuai dengan kerangka berpikir yang dimilikinya. Dengan demikian, pendekatan pembelajaran kontekstual memberikan kesempatan seluas-luasnya kepada siswa untuk mengungkapkan gagasan-gagasannya dan perolehan informasi dalam belajar sesuai dengan kebutuhan siswa.

Dengan pembelajaran seperti di atas menuntut penilaian penguasaan siswa terhadap materi pelajaran matematika dengan cara yang lebih autentik dibanding asesmen sederhana yang hanya mengakses sebagian kecil pengetahuan siswa. Tidak cukup hanya dengan asesmen konvensional yang hanya memberikan gambaran sebagian dan sesaat terhadap kinerja siswa. Dengan asesmen seperti itu akan kurang mendukung efektivitas pendekatan pembelajaran kontekstual yang diterapkan. Siswa belajar untuk aktif, kreatif, bertukar pendapat, melakukan presentasi, bertukar informasi, memecahkan masalah matematika tetapi yang dinilai hanya sebagian kecil dari penampilan/kemampuan siswa. Tentunya akan menimbulkan kerugian yang besar bagi guru maupun siswa, karena tidak sejalan antara pembelajaran yang diterapkan dengan asesmen yang digunakan.

Dibutuhkan asesmen yang mampu mengakses kemampuan siswa secara holistik. Asesmen tersebut adalah asesmen kinerja. Dalam asesmen kinerja siswa dan guru akan diberikan kesempatan untuk melakukan evaluasi diri yang dilakukan pada setiap akhir pembelajaran, siswa dapat melihat kelebihan maupun kekurangannya, untuk selanjutnya kekurangan ini menjadi tujuan perbaikan. Hal ini berakibat pada meningkatnya tanggung jawab siswa terhadap proses dan pencapaian tujuan belajarnya, yang nantinya diharapkan pada meningkatnya hasil belajar matematika. Hal ini sesuai dengan hasil penelitian Pantiwati (2010) yang menemukan ada perbedaan kemampuan kognitif antara siswa yang penilaiannya menggunakan asesmen autentik dengan asesmen konvensional dalam pembelajaran kooperatif TPS (Think Pair Share). Penggunaan asesmen autentik berpengaruh lebih tinggi dan berbeda signifikan terhadap kemampuan kognitif dibanding dengan penggunaan asesmen konvensional.

Asesmen kinerja matematika adalah suatu bentuk penilaian terhadap presentasi tugas matematika, kemampuan memecahkan masalah matematika, proyek matematika, observasi, dan hasil kerja (produk) yang menggambarkan kemampuan siswa melalui suatu proses, kegiatan, unjuk kerja maupun hasil dari cerminan proses yang dilakukan oleh siswa. Sifat kegiatan dari asesmen kinerja berdasarkan kehidupan nyata. Oleh karena itu, terlihat adanya kesesuaian antara penggunaan asesmen kinerja dalam pembelajaran dengan pendekatan pembelajaran kontekstual, yaitu: sama-sama berdasarkan kehidupan nyata siswa.

Dengan demikian wajar hasil belajar matematika siswa yang diberikan asesmen kinerja lebih tinggi daripada siswa yang diberikan asesmen konvensional, setelah mengontrol bakat numerik.

Hasil pengujian hipotesis ketujuh menunjukkan bahwa untuk siswa yang mengikuti pendekatan pembelajaran konvensional, hasil belajar matematika siswa yang diberikan asesmen kinerja lebih rendah daripada siswa yang diberikan asesmen konvensional, setelah mengontrol bakat numerik.

Pembelajaran konvensional merupakan pembelajaran yang biasa dilakukan guru dalam proses belajar mengajar di dalam kelas. Pada pembelajaran konvensional, proses belajar mengajar lebih sering diarahkan pada "aliran informasi" atau "transfer" pengetahuan dari guru ke siswa. Konsep yang diterima siswa hampir semuanya berasal dari "apa kata guru". Dalam pembelajaran ini guru cenderung mengontrol proses pembelajaran secara aktif, sementara siswa relatif pasif dan hanya mengikuti apa yang disajikan oleh guru. Dengan kondisi tersebut kecil kemungkinan guru mampu mengakses penampilan (performance) siswa, karena yang aktif dalam pembelajaran adalah guru bukan siswa. 
Keterlaksanaan asesmen kinerja dalam pembelajaran tergantung sangat ditentukan oleh tingkat keaktifan guru dan peserta didik selama mengikuti proses pembelajaran. Makin rendah tingkat keaktifan kreativitas peserta didik dan guru makin rendah pula tingkat keefektifan asesmen kinerja bahkan mungkin tidak dapat berjalan dengan baik. Sehingga apa yang dilakukan siswa akan menjadi kumpulan tugas-tugas yang tidak ada artinya. Sehingga kurang memotivasi siswa untuk belajar.

Dalam pendekatan pembelajaran konvensional guru akan merasa bangga ketika anak didiknya mampu menyebutkan kembali secara lisan (verbal) sebagian besar informasi yang terdapat dalam buku teks atau yang diberikan oleh guru. Siswa yang pengetahuannya diakses dengan asesmen konvensional akan lebih suka mengikuti langkah-langkah belajar yang terurut (algoritmik) dan jelas karena umumnya suka menerima apa yang sudah ada. Hal-hal yang tidak biasa akan diabaikan. Penerapan asesmen konvensional akan membuat siswa kurang kreatif, tidak menyukai tantangan, lambat dalam bertukar informasi, serta kurang mampu berinteraksi di dalam kelas. Pembelajaran model ini akan lebih cocok mengikuti pendekatan pembelajaran konvensional, karena pendekatan ini siswa dituntut menerima informasi dengan sedikit respon.

\section{Kesimpulan}

Dari hasil pengujian hipotesis dengan menggunakan ANAKOVA yang dilanjutkan dengan uji perbedaan, setelah mengontrol bakat numerik dapat ditarik kesimpulan sebagai berikut: Hasil belajar matematika siswa yang mengikuti pendekatan pembelajaran kontekstual lebih baik dari pada siswa yang mengikuti pendekatan pembelajaran konvensional, hasil belajar matematika siswa yang diberikan asesmen kinerja lebih tinggi dari pada siswa yang diberikan asesmen konvensional. Lebih jauh terdapat interaksi antara pendekatan pembelajaran dengan bentuk asesmen formatif terhadap hasil belajar matematika. Untuk siswa yang mengikuti pendekatan pembelajaran kontekstual lebih cocok diberikan asesmen kinerja, sedangkan untuk siswa yang mengikuti pendekatan pembelajaran konvensional lebih cocok diberikan asesmen konvensional.

\section{Daftar Pustaka}

Ariesta, Indah Wahyu. (20I2). Efektivitas Pendekatan Pembelajaran Kontekstual Ditinjau dari Sikap dan Kemampuan Pemecahan Masalah Matematis Siswa. Jurnal Pendidikan Matematika, I (4), November.

Al-Sadaawi. (2008). An Investigation Of Performance-Based Assessment In Science In Saudi Primary Schools. Paper presented at the 34th IAEA Annual Conference, Cambridge UK, September.

Berns, Robert G., dan Patricia M. Erickson. Contextual Teaching and Learning: Preparing Students for the New Economy. The Highlight, Zone Research @work. http://www.cord.org/ uploadedfiles/nccte_highlight 05-contextual teachinglearning.pdf (diakses 2 Maret 20I2).

Butler, Susan M., dan Nancy D. McMunn. (2006). Classroom Assessment. San Francisco: JosseyBass.

Carter, Philip. (2007). IQ and Aptitude Tests. London: Kogan Page Limited.

Danielson. A Collection of Performance Task and Rubric. http://www.assesment.com/ Danielson/I0/4/2006 (diakses 6 Desember 20I2).

\section{Elliott, Stephen N. Creating Meaningful Performance Assessment. Online. http://ericae.net/edo/ ED381985.htm (diakses I Maret 20I3).}

Gita, Nyoman. (2007). Implementasi Pendekatan pembelajaran kontekstual Untuk Meningkatkan Hasil Belajar Matematika Siswa di Sekolah Dasar. Jurnal Penelitian dan Pengembangan Pendidikan, I (I): 26-34.

Johnson, Elaine B. (20I2). Contextual Teaching and Learning menjadikan Kegiatan Belajar Mengajar Mengasyikkan dan Bermakna, 
terjemahan Chaedar Alwasilah. Bandung: Kaifa.

Kadir. Meningkatkan Metakognisi Siswa Dalam Pelajaran Matematika Melalui Asesmen Kinerja Berbasis Masalah dan Model Pembelajaran. Jurnal Penelitian Pendidikan Agama dan Keagamaan, VII(3), September: 88-108.

Kalchik, Stephanie dan Kathleen Marie Oertle. (2010). The Theory and Application of Contextualized Teaching and Learning in Relation to Programs of Study and Career Path ways. Transition Highlights, Issue 2, September: I-3.

Kerlinger, Fred N. (1990). Asas-asas Penelitian Behavioral, terjemahan Landung $\mathrm{R}$. Simatupang. Yogyakarta: Gajah Mada University Press.

Lee K. Chiou. (2007). Alternative Assessment in My Mathematics Classroom. Jurong: Pearson Education Pte. Ltd.

Nitko, Anthony J. (1996). Educational Assessment of Student. New Jersey: Prentice-Hall, Inc.
Pantiwati, Yuni. (20I0). Pengaruh Jenis Asesmen Biologi dalam Pembelajaran Kooperatif TPS (Think Pair Share) terhadap Kemampuan Kognitif, Bepikir Kritis, Berpikir Kreatif, dan Kesadaran Metakognitif Siswa SMA di Kota Malang. Disertasi, Universitas Negeri Malang.

Putra, Aditia. (20/2). Pengaruh Pendekatan Pembelajaran Kontekstual (CTL) Ditinjau dari Bakat Numerik dalam Meningkatkan Hasil Belajar Matematika di Kelas VIII SMP Negeri II Denpasar. Jurnal Penelitian, 2(2): I-I5.

Sears, Susan. (2000). Teaching and Learning: A Primer for Effective Instruction. Bloomington: Phi Delta Kappa Educational Foundation.

Semiawan, Conny. (1997). Perspektif Pendidikan Anak Berbakat. Jakarta: Grasindo.

Wardhani, Sridan Rumiati. (2004). Penilaian Pembelajaran Matematika Berbasis Kompetensi. Yogyakarta: Departemen Pendidikan Nasional. 